Jose M. Carnate, Jr., MD

Department of Pathology

College of Medicine

University of the Philippines Manila

Correspondence: Dr. Jose M. Carnate, Jr. Department of Pathology

College of Medicine, University of the Philippines Manila 547 Pedro Gil St., Ermita, Manila 1000

Philippines

Phone (632) 5264450

Fax (632) 4003638

Email:jmcjpath@yahoo.com

Reprints will not be available from the author.

The author declared that this represents original material that is not being considered for publication or has not been published or accepted for publication elsewhere, in full or in part, in print or electronic media; that the manuscript has been read and approved by the author, that the requirements for authorship have been met by the author, and that the author believes that the manuscript represents honest work.

Disclosures: The author signed disclosures that there are no financial or other (including personal) relationships, intellectual passion, political or religious beliefs, and institutional affiliations that might lead to a conflict of interest.

\section{Spindle Cell Carcinomas of the Upper Aerodigestive Tract}

A 65-year-old male with a two-month history of cough and hoarseness underwent direct laryngoscopy which showed a $1.5 \mathrm{~cm}$ diameter polypoid glottic mass. A polypectomy was performed revealing spindle cell carcinoma.

The World Health Organization (2005) defines a spindle cell carcinoma as "a biphasic tumor composed of a squamous cell carcinoma, either in-situ and/or invasive, and a malignant spindle cell component with a mesenchymal appearance, but of epithelial origin."' Spindle cell carcinomas go by a variety of synonyms such as sarcomatoid carcinoma, spindle cell squamous carcinoma and carcinosarcoma.

The larynx is a preferred site of involvement where they often present as polypoid masses. ${ }^{1,3}$ Microscopic examination often shows predominance of the sarcomatoid, spindle-cell component, which can range from fairly bland, reactive-looking fibroblastic-proliferation-like processes, to cytologically malignant and mitotically active proliferations that mimic other spindle-cell sarcomas such as leiomyosarcoma, fibrosarcoma or malignant fibrous histiocytoma. ${ }^{1,2,3}$ (Figure 1, double arrows) The squamous cell carcinoma component may be in the form of an overlying carcinoma-in-situ, or of a focal keratinizing invasive squamous cell carcinoma that requires multiple sections to disclose. ${ }^{1,2}$ (Figure 1, single arrow) Cytokeratin-reactivity in the spindle cells, which may be quite focal as in this case, points to their epithelial derivation. 1,2, (Figure 2)

Favorable prognostic findings include polypoid morphology and, like conventional laryngeal squamous cell carcinomas, a low-stage and a glottic site of origin. Reported 5-year survival rates range from $65-95 \%{ }^{1}$ 


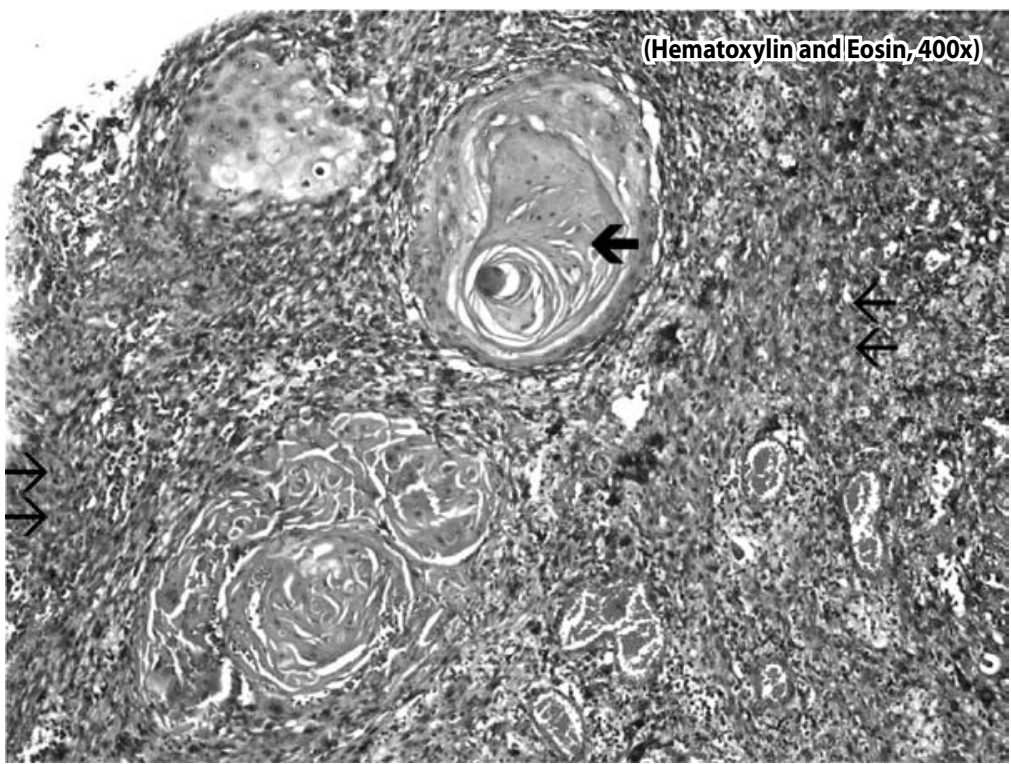

Figure 1. Predominant malignant spindle cell component (double arrows) with focal keratinizing squamous cell carcinoma component (single arrow) (Hematoxylin and Eosin, 400x)

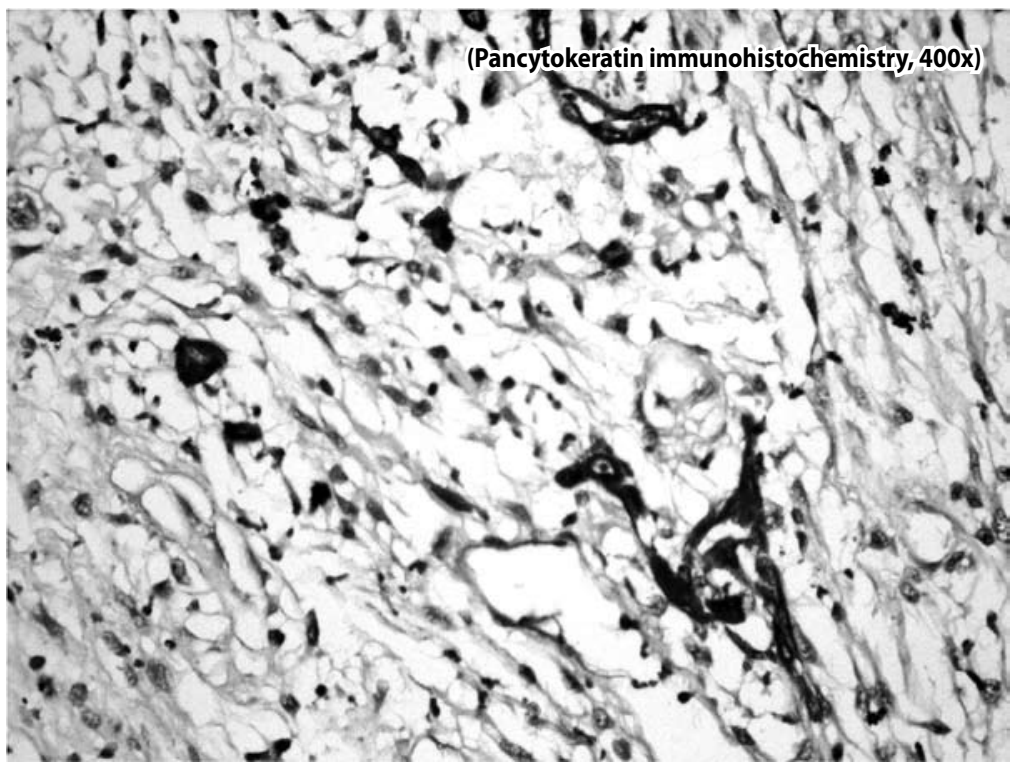

Figure 2. Focal cytokeratin reactivity among spindle cells, (Pancytokeratin immunohistochemistry, 400x)

\section{REFERENCES}

1. Barnes L, Eveson JW, Reichart P, Sidransky D. Pathology and Genetics of Head and Neck Tumors In WHO Classification of Tumors. International Agency for Research on Cancer (IARC) Press, Lyon 2005.

2. Gnepp DR, ed. Diagnostic Surgical Pathology of the Head and Neck. WB Saunders Company, 2009.

3. Thompson LD, Wieneke JA, Miettinen M, Heffner DK. Spindle cell (sarcomatoid) carcinomas of the larynx: a clinicopathologic study of 187 cases. Am J Surg Pathol. 2002 Feb; 26(2):153-170.

4. Lewis JE, Olsen KD, Sebo TJ. Spindle cell carcinoma of the larynx: review of 26 cases including DNA content and immunohistochemistry. Hum Pathol. 1997 Jun; 28(6):664 - 673. 